\title{
Companion to Central and Eastern European Humanism: The Czech Lands, Part 1. Edited by Lucie Storchová.
}

Berlin: De Gruyter, 2020. 798 pp. https://doi.org/10.1515/9783110650181

\section{Borbála Lovas}

Humanism in East Central Europe Research Group, Faculty of Humanities, Eötvös Loránd University, Múzeum krt. 4/A, H-1088 Budapest, Hungary; lovasborbala@gmail.com

The Companion to Central and Eastern European Humanism: The Czech Lands, the first work in English to give an overall view of the Humanists, their life, and literary activities in the region, is the first of two published volumes of a remarkable Central European project. A series of companions presents Humanist literary activities in Hungary (including Transylvania, Upper Hungary, and the southern territories), the Czech Lands, Poland (the Polish-Lithuanian Commonwealth), Croatia, and Austria, expounding for the first time in English the unique history of a rich literary heritage in its complexity, showing a new side of this broad intellectual movement. The main editors of this fascinating project are Christian Gastgeber and Farkas Gábor Kiss. The entries in each volume, as we see in this first printed edition, give us a detailed description of each author's life and work, following the tradition of the Verfasserlexikon series, offering not only titles and summaries but more specific details of the remaining copies, printed matter, and manuscripts, as well as the related secondary literature. A productive collaboration of an international team of researchers, the first Czech volume that introduces the Humanist authors in the Bohemian context was edited by Lucie Storchová. The Czech part of this project, based at the Institute of Philosophy of the Czech Academy of Sciences, began in 2016. The entries of the Humanists listed in the first volume contain the names of authors active between the last third of the fifteenth century and the first third of the seventeenth century. They were born or worked for a longer period in the Czech lands, or were connected to the Czech nobility or Czech scholarly circles. Inspired by ancient authors, the Humanists discussed wrote in Latin or Greek, edited ancient classics, or translated them into the vernacular. The entries introduce the authors' entire oeuvre, including their original items in the vernacular (in Czech and German), and ecclesiastic and other works. 
The first part of the Companion on the Czech lands shows us how this project opens an entire area for researchers, since besides some major figures and some parts of the history of Renaissance Humanism in East-Central Europe presented in recent monographs, most authors have been little-known. They have only been introduced in regional publications or are presented to wider audiences for the first time in the Companion series. The first volume contains entries with surnames ranging from $\mathrm{A}$ to $\mathrm{L}$ and will soon be followed by the second to cover the rest of the authors.

In addition to the entries of names, the book offers much more. Czech scholars summarize the development of Renaissance Humanism in three chapters, outlining the literary and political context of the period. In the first paper, Petr Voit presents Czech Humanism in the first half of the sixteenth century, showing how the early impact of Humanist ideas was different from European patterns because of a weak educational system, religious diversity, and the strong influence religious polemics had on literary interests. In the second paper, Lucie Storchová introduces Humanist literature in the area during the four decades from the 1550s and the changing role of the classical tradition in the Czech literary world, affected by the Reformation, social changes, and book printing. Beginning with the first generation of Czech students who studied in Wittenberg, Czech Humanists returned from Protestant Universities, or were educated at and later taught at the University of Prague, in town schools or private schools, produced poetry on biblical and theologically relevant themes, as well as scholarly, political, and occasional poems. They began to produce editions of the classics for educational purposes, organized the regional literary life, and trained and mentored subsequent Humanist generations. Later, this Humanist literature was influenced by religious diversification and the activity of an extensive international scholarly network. The final paper, written by Jan Malura and Marta Vaculínová, focuses on late Humanism between the 1590s and 1620s. A change in the tone of literary works in this period was brought about by historical, political, and cultural events. Prague became the new center of the Imperial Court, the presence of the Ottoman threat was oppressive, and the endless fights within the Empire were pregnant with political and military conflict.

The lexicon entries are divided into three sections: Biography, Work, and Bibliography. The pieces show a wide range of type and style, beginning with Latin Humanist poetry, disputations, commentaries, theatrical plays, historiography, astronomical and astrological works, political tracts, dictionaries, grammars, translations, and correspondence, including entries in alba amicorum, religious poems in Latin and the vernacular, sermons and polemics, prayers, and teaching manuals. The descriptions offer an insight into the active literary network of the period and the region, and highlight often-used sources, preferred topics and forms, and the afterlife of the works. 
The first published volume already shows the usefulness of this multi-volume reference work for researchers of the field and a wider readership. The entries do not only give a rich description of the authors' life and works, but also detailed introductions to their variety. Readers can find names of widely known Humanists, scholars, teachers, and printers, like Johannes Kepler, Augustinus Moravius, Tomáš Jordán, Ioannnes Dubravius, Petrus Codicillus, Jan Kocín, or Jan Günther, as well as less noted authors, like Theophilus Crysteccus, Iacobus Iacobaeus, Václav Faber, Abraham of Günterrod, and others. Each entry provides catalog numbers and VD numbers, a list of available editions, and a selected bibliography concerning the authors.

The Companion to Central and Eastern European Humanism demonstrates how the East-Central European region was connected to better-researched areas in Europe in the fifteenth to the early seventeenth century, and how the region's Humanism and literary tradition can be interpreted in the light of the contemporary history of Humanist literature. 